\title{
Metal-on-metal bearings in total hip arthroplasties: Influence of cobalt and chromium ions on bacterial growth and biofilm formation
}

\author{
Anton H. Hosman, ${ }^{1,2}$ Henny C. van der Mei, ${ }^{1}$ Sjoerd K. Bulstra, ${ }^{2}$ Henk J. Busscher, ${ }^{1}$ Daniëlle Neut ${ }^{1,2}$ \\ ${ }^{1}$ Department of Biomedical Engineering, University Medical Center Groningen, Antonius Deusinglaan 1, \\ 9713 AV Groningen, The Netherlands \\ ${ }^{2}$ Department of Orthopaedic Surgery, University Medical Center Groningen, Antonius Deusinglaan 1, \\ 9713 AV Groningen, The Netherlands
}

Received 4 September 2007; revised 30 November 2007; accepted 5 December 2007

Published online 11 March 2008 in Wiley InterScience (www.interscience.wiley.com). DOI: 10.1002/jbm.a.31922

\begin{abstract}
Metal-on-metal (MOM) bearings involving cobalt-chromium (Co-Cr) alloys in total hip arthroplasties are becoming more and more popular due to their low wear. Consequences of corrosion products of $\mathrm{Co}-\mathrm{Cr}$ alloys are for the most part unclear, and the influence of cobalt and chromium ions on biofilm formation has never been studied. Therefore, the aim of this study was to evaluate how $\mathrm{Co}-\mathrm{Cr}$ ions affect bacterial growth, biofilm formation, and architecture. A collection of clinically isolated and commercially available bacterial strains were exposed to $\mathrm{Co}-\mathrm{Cr}$ concentrations as found in serum and above as found in adjacent tissue. Planktonic growth of bacteria was inhibited by concentrations of 200,000/93,000 $\mu \mathrm{g} / \mathrm{L} \mathrm{Co-Cr}$. $\mathrm{Co}-\mathrm{Cr}$ concentrations up to $20 / 9.3 \mu \mathrm{g} / \mathrm{L}$ as reported to occur in serum revealed no consistent influence on bio-
\end{abstract}

film formation, but higher concentrations of 200,000/93,000 $\mu \mathrm{g} / \mathrm{L}$ significantly reduced Staphylococcus aureus and CNS biofilm formation. As indicated by confocal laser scanning microscopy, no dead bacteria were encountered in the biofilms, and the metal ion concentrations used must be classified as growth-inhibiting and not bactericidal. Long-term clinical data on infection rates for $\mathrm{Co}-\mathrm{Cr}$ MOM-bearings are not yet available, but the current results suggest that $\mathrm{Co}-\mathrm{Cr}$ ions may yield these prostheses less prone to biofilm formation and subsequent infection. (C) 2008 Wiley Periodicals, Inc. J Biomed Mater Res 88A: 711-716, 2009

Key words: metal-on-metal bearing; infection; cobalt; chromium; biofilm formation

\section{INTRODUCTION}

Total hip replacement is a highly successful procedure with a regain of a relatively high quality of life and an almost instant pain relief. Success of the procedure resulted in younger cohorts of patients. Many of these younger patients want to return to a high level of activity and seek an implant that provides durability. Larger femoral heads were indicated, ${ }^{1}$ but this tended to cause excessive wear in conventional prostheses (metal ball connected to large stem and a cup with polyethylene interface). Polyethylene wear and debris is a suspected cause of osteolysis around the implant, ${ }^{2,3}$ which led to the development of alternative bearings lacking a polyethylene/metal interface, like the recently reintroduced metal-on-metal (MOM) bearings. In contrast to metal-on-polyethylene

\section{Correspondence to: D. Neut; e-mail: d.neut@med.umcg.nl}

(C) 2008 Wiley Periodicals, Inc. bearings, wear rates of MOM-bearings turned out to be impacted in a positive way by increasing the head size $^{4,5}$ yielding 20-100 times less debris than in traditional metal-on-polyethylene bearings. ${ }^{6}$ The remarkably low wear of MOM-bearings has led to a rapidly increasing popularity of MOM-articulation in the treatment of young and active patients. ${ }^{7}$

Although mid- and long-term clinical results of MOM-bearings appeared to have demonstrated excellent durability, recent studies show that there is at least one MOM-bearing system with periprosthetic osteolysis and aseptic loosening, which is possibly associated with hypersensitivity to metal debris. ${ }^{8,9}$ Additionally, MOM-articulations are not completely biologically inert, since they produce metal particles that can be found in, for example, blood and urine. These particles tend to corrode and serum levels of metal ions, mainly cobalt and chromium, become elevated. ${ }^{10-15}$ Cobalt and chromium are usually eliminated only slowly from the body by urine, and chromium is even retained in the body's tissues. ${ }^{10,16}$ These high cobalt and chromium serum 
TABLE I

The Percentage of Growth Stimulation/Reduction After 24 h of Metal Ion Exposure

\begin{tabular}{|c|c|c|c|c|}
\hline & \multicolumn{4}{|c|}{$\mathrm{Co} / \mathrm{Cr}$ Ion Concentration $(\mu \mathrm{g} / \mathrm{L})$} \\
\hline & $2 / 0.93$ & $20 / 9.3$ & $20,000 / 9300$ & $200,000 / 93,000$ \\
\hline \multicolumn{5}{|l|}{ Staphylococcus aureus } \\
\hline Staphylococcus aureus 5296 & $4 \%$ & $-4 \%$ & $-8 \%$ & $-12 \%$ \\
\hline Staphylococcus aureus 7388 & $-3 \%$ & $-7 \%$ & $-10 \% *$ & $-17 \% *$ \\
\hline Staphylococcus aureus ATCC 12600 & $15 \%$ & $9 \%$ & $-15 \%$ & $-35 \% *$ \\
\hline Staphylococcus aureus ATCC 25923 & $-4 \%$ & $0 \%$ & $0 \%$ & $-11 \% *$ \\
\hline Staphylococcus aureus ATCC 51153 & $4 \%$ & $4 \%$ & $0 \%$ & $0 \%$ \\
\hline Mean $(\mathrm{SD}=8 \%$ ) & $3 \%$ & $0.4 \%$ & $-7 \%$ & $-15 \%$ * \\
\hline \multicolumn{5}{|l|}{ CNS } \\
\hline CNS 7391 & $4 \%$ & $-6 \%$ & $-20 \%$ & $-45 \% *$ \\
\hline CNS 5115 & $-9 \%$ & $-7 \%$ & $-11 \%$ & $-20 \%$ \\
\hline CNS 5295 & $7 \%$ & $11 \%$ & $0 \%$ & $-4 \%$ \\
\hline CNS 7319 & $-4 \%$ & $0 \%$ & $-8 \%$ & $-8 \%$ \\
\hline CNS 7349 & $-4 \%$ & $4 \%$ & $-32 \% *$ & $-47 \% *$ \\
\hline CNS 5147 & $-9 \%$ & $-2 \%$ & $-9 \%$ & $-38 \% *$ \\
\hline CNS ATCC 35984 & $10 \%$ & $21 \% *$ & $5 \%$ & $-28 \% *$ \\
\hline CNS ATCC 14990 & $-3 \%$ & $0 \%$ & $3 \%$ & $-21 \% *$ \\
\hline Mean $(S D=13 \%)$ & $-1 \%$ & $3 \%$ & $-9 \%$ & $-26 \% *$ \\
\hline
\end{tabular}

*Indicates a significant difference versus growth in the absence of metal exposure, i.e. $0 \%$ growth stimulation/reduction $(p<0.05)$.

Values are averages including standard deviations from three experiments with separately cultured bacteria, yielding an average mean standard deviation of $11 \%$. Note that mean values in bold represent the mean including standard deviations over the collection of isolates involved. Growth reductions appear as negative numbers.

concentrations may have toxic effects, which include the increase of bone resorption, and theoretical risks of delayed-type hypersensitivity, organ toxicity, and altering of cell homeostasis. ${ }^{17-22}$ Furthermore, cobalt and chromium have been shown to be carcinogenic and mutagenic in human and animal models, ${ }^{23-26}$ which implies that systemic toxicity and cancer risk may be possible disadvantages of MOM-articulation.

Alongside these possible disadvantages, it is also conceivable that the risk of infection is influenced by metal ions. Infection still remains a significant complication following total hip replacement and as a conservative estimate, affects about $1-2 \%$ of all patients during the life time of an implant. ${ }^{27}$ In case of infection, bacteria adapt a biofilm mode of growth on the surface of the prosthesis, which represents a basic survival mechanism of the organisms ${ }^{28}$ to external (500-5000 times increased antibiotic resistance ${ }^{29,30}$ ) and internal environmental factors (the host immune system). The increased antibiotic resistance of biofilms causes major difficulties in patient treatment. Removal and replacement of an infected implant is usually required to eliminate the infection with accompanying trauma and increased costs to the health service. ${ }^{31-33}$ Copper and zinc are known for their bactericidal properties and impact on biofilm formation, ${ }^{34}$ but no research efforts have been undertaken towards the specific influence of the cobalt-chromium ion combination on biofilm formation, despite extensive other studies into MOM-bearings. ${ }^{35-37}$

The aim of this in vitro study is to evaluate the influence of cobalt and chromium ions on bacterial growth, biofilm formation, and architecture for a collection of clinically isolated and commercially available bacterial strains.

\section{MATERIALS AND METHODS}

\section{Bacterial strains}

Gram-positive organisms account for most bacteria found in infected hip arthroplasties. Coagulase negative staphylococcus $(67 \%)$ was found to be the predominant organism, although Staphylococcus aureus (13\%) is gaining importance. $^{38}$ Therefore, a total of 13 staphylococcal strains were used in this study (Table I), chosen to represent their frequency of occurrence in clinical infection. Eight strains were isolated with extensive biomaterial culturing ${ }^{39}$ from explanted metal-on-polyethylene joint prostheses from individual patients with septic loosening and retrieved during revision surgery (Department of Orthopaedic Surgery at the University Medical Center Groningen, The Netherlands) and five additional strains were of ATCC origin.

\section{Cobalt and chromium ions}

Metal ion concentrations of 2/0.93; 20/9.3; 20,000/9300; $200,000 / 93000 \mu \mathrm{g} / \mathrm{L} \mathrm{Co}-\mathrm{Cr}$ were applied throughout this study. The lowest Co concentration of $2 \mu \mathrm{g} / \mathrm{L}$ was inline with previously found Co serum concentrations ${ }^{11-15}$ and the proportion $\mathrm{Co}-\mathrm{Cr}$ in this study was chosen similar to most MOM-bearings currently used in Europe $( \pm 61 \% \mathrm{Co}$ and $29 \% \mathrm{Cr}$ ). The second-lowest level of $20 / 9.3 \mu \mathrm{g} / \mathrm{L} \mathrm{Co}-$ $\mathrm{Cr}$ was chosen to represent higher serum levels, described in the literature. Higher concentrations of metal ions were 
used, since the local concentration of metal ions in the synovial fluids is expected to be much higher than the serum concentrations.

Based on a previously described method, ${ }^{40} 0.847 \mathrm{mg}$ cobalt salt $\left(\mathrm{CoCl}_{2} \cdot 6 \mathrm{H}_{2} \mathrm{O}\right.$, Sigma) and $0.475 \mathrm{mg}$ chromium salt $\left(\mathrm{CrCl}_{3} \cdot 6 \mathrm{H}_{2} \mathrm{O}\right.$, Merck) were dissolved in $10 \mathrm{~mL}$ tryptone soya broth (TSB) (Oxoid, Basingstoke, United Kingdom). These samples contained 200,000/93,000 $\mu \mathrm{g} / \mathrm{L} \mathrm{Co-Cr}$ and were diluted with broth to reach the concentrations and Co-Cr proportions needed for the experiments.

\section{Planktonic growth evaluation}

Three S. aureus strains and two CNS strains were randomly chosen for growth curve evaluation. These isolates were routinely cultured from frozen stock on blood agar plates at $37^{\circ} \mathrm{C}$ for $24 \mathrm{~h}$. Precultures were inoculated with a single plate colony, grown in $10 \mathrm{~mL}$ TSB and incubated aerobically overnight at $37^{\circ} \mathrm{C}$. From the resulting suspension, $1 \mathrm{~mL}$ was inoculated overnight with $45 \mathrm{~mL}$ TSB, $45 \mathrm{~mL}$ TSB with $20,000 / 9300 \mu \mathrm{g} / \mathrm{L}$ Co-Cr or $45 \mathrm{~mL}$ TSB with 200,000/93,000 $\mu \mathrm{g} / \mathrm{L}$ Co-Cr. The absorbance at $600 \mathrm{~nm}$ $\left(\mathrm{A}_{600}\right)$ was determined using a spectrophotometer. All growth curve experiments were performed twice with separately cultured bacteria.

\section{Biofilm formation in microtiter plates}

All strains mentioned in Table I were routinely cultured from frozen stock on blood agar plates at $37^{\circ} \mathrm{C}$ for $24 \mathrm{~h}$. Precultures were inoculated with a single colony from plate grown in $10 \mathrm{~mL}$ TSB and incubated overnight aerobically at $37^{\circ} \mathrm{C}$. A bacterial suspension of $200 \mu \mathrm{L}(2 \mu \mathrm{L}$ preculture and $198 \mu \mathrm{L}$ fresh TSB) supplemented with different concentrations of metal ions, was used to inoculate a well of a 96-well polystyrene flat-bottomed tissue culture plate (Falcon, Becton Dickinson, Oxnard, CA) for biofilm formation. After $24 \mathrm{~h}$ at $37^{\circ} \mathrm{C}$, the growth media and planktonic cells in the 96-wells plates were removed from the biofilms by carefully replacing the volume of the wells twice with $200 \mu \mathrm{L} 10 \mathrm{mM}$ potassium phosphate, $\mathrm{pH} 7.0$ by pipetting, while taking care that air-liquid interface passages over the biofilms were avoided. The wells were subsequently stained with $200 \mu \mathrm{L} \mathrm{1 \%}$ crystal violet. After $30 \mathrm{~min}$, excess stain was replaced with $200 \mu \mathrm{L}$ demineralised water as described above, and the crystal violet was dissolved in $200 \mu \mathrm{L}$ of ethanol-aceton (80:20 vol/vol). The absorbance at $575 \mathrm{~nm}\left(\mathrm{~A}_{575}\right)$ was determined using a microtiter plate reader (Fluostar Optima) to determine the amount of crystal violet, as a measure of biofilm growth. The influence of $\mathrm{Co}-\mathrm{Cr}$ ions on biofilm formation was evaluated by measuring the percentage of growth stimulation/reduction according to

growth stimulation/reduction

$$
=\frac{\left(\mathrm{A}_{575} \text { presence } \mathrm{Co}-\mathrm{Cr}-A_{575} \text { absence } \mathrm{Co}-\mathrm{Cr}\right)}{\mathrm{A}_{575} \text { absence } \mathrm{Co}-\mathrm{Cr}} \times 100
$$

Thus inhibitory effects of the presence of $\mathrm{Co}-\mathrm{Cr}$ ions appear as negative numbers in the outcome parameter. All experiments included six replicate wells and were performed three times with separately cultured bacteria.

\section{Biofilm architecture determination by confocal laser scanning microscopy}

Two of the five strains used for growth curve evaluation, S. aureus 7388 and a CNS 5147, were used for visualizing biofilm architecture. These isolates were routinely cultured from frozen stock on blood agar plates at $37^{\circ} \mathrm{C}$ for $24 \mathrm{~h}$. Precultures were inoculated with a single colony from plate grown in $10 \mathrm{~mL}$ TSB and incubated overnight aerobically at $37^{\circ} \mathrm{C}$. From the above mentioned bacterial suspension, $25 \mu \mathrm{L}$ was inoculated with respectively $3 \mathrm{~mL}$ TSB, $3 \mathrm{~mL}$ TSB with 2/0.93 $\mu \mathrm{g} / \mathrm{L}$ Co-Cr or $3 \mathrm{~mL}$ TSB with 200,000/93,000 $\mu \mathrm{g} / \mathrm{L} \mathrm{Co-Cr}$ in a 6-wells polystyrene tissue culture plate (Costar). After $24 \mathrm{~h}$ of incubation at $37^{\circ} \mathrm{C}$, biofilms were stained with calcofluor white (Bayer) to visualize extracellular polymeric substance (fluorescent blue), and with LIVE/DEAD Baclight viability kit (Molecular Probes Inc., Eugene, Oreg.), to visualize live (fluorescent green) and dead (fluorescent red) bacteria. After $15 \mathrm{~min}$ incubation in the dark, confocal images were collected using a Leica TCS-SP2 microscope with a $40 \times$ water objective. Images were obtained at 1-2 $\mu \mathrm{m}$ intervals down through the biofilm and the number of images, therefore, corresponded with the thickness of the biofilm. The confocal laser scanning microscopy (CLSM) experiments were performed twice with separately cultured bacteria.

\section{Statistical analysis}

Differences in optical densities of biofilms grown in the absence and presence of metal ions were analyzed for significance by the Student $t$-test for paired samples. A $95 \%$ $(p<0.05)$ confidence interval was applied for statistical significance.

\section{RESULTS}

\section{Planktonic growth}

Figure 1 summarizes the planktonic growth of S. aureus 7388 and a CNS 5147 in the absence and presence of different concentrations of $\mathrm{Co}-\mathrm{Cr}$ ions. Clearly for these two strains as well as for the other three strains involved in planktonic growth experiments (data not shown), planktonic growth was not significantly influenced by $\mathrm{Co}-\mathrm{Cr}$ as compared with the control when the ion concentrations were less than 20,000/9300 $\mu \mathrm{g} / \mathrm{L} \mathrm{Co-Cr}$, but at the highest concentration of 200,000/93,000 $\mu \mathrm{g} / \mathrm{L} \mathrm{Co-Cr}$ all S. aureus and CNS strains showed significant growth reduction. 
S. aureus 7388

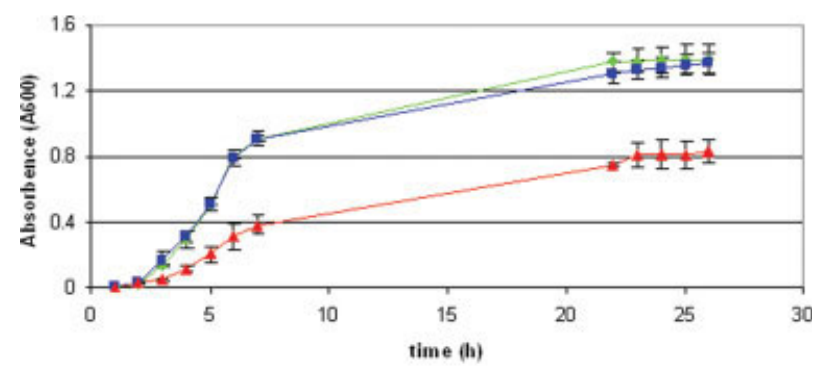

CNS 5147

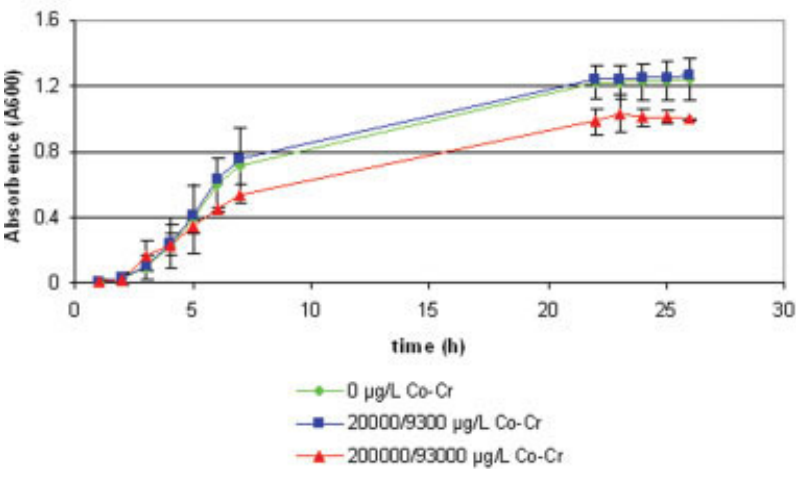

Figure 1. Growth curves of two clinically isolated strains: S. aureus 7388 and CNS 5147 in the absence and presence of metal ions. Error bars indicate the standard deviation of the mean calculated from two growth curve experiments with separately cultured bacteria. [Color figure can be viewed in the online issue, which is available at www. interscience.wiley.com.]

\section{Biofilm formation}

Table I summarizes the effects of different concentrations of $\mathrm{Co}-\mathrm{Cr}$ ions on biofilm formation of the $S$. aureus and CNS strains involved. Whereas most isolates show growth reductions that increase with increasing $\mathrm{Co}-\mathrm{Cr}$ concentrations, some strains are clearly stimulated in their growth at low metal ions concentrations (S. aureus ATCC 12600 and CNS ATCC 35984). At the highest metal ion concentrations, however, all strains are reduced in their growth. When averaged over all isolates of a given species, it becomes clear that $S$. aureus and CNS are inhibited in their growth when $\mathrm{Co}-\mathrm{Cr}$ concentrations are above 200,000/93,000 $\mathrm{g}$ / L. At that concentration, CNS is slightly more affected than $S$. aureus.

\section{Biofilm architecture}

CLSM images of the S. aureus 7388 and CNS 5147 biofilms grown in the absence and presence of Co$\mathrm{Cr}$ ions revealed a decrease in the number of live bacteria due to the presence of $\mathrm{Co}-\mathrm{Cr}$ ions (see Fig. 2). Sectional analysis of each biofilm layer (about $1 \mu \mathrm{m}$ in thickness) made it possible to demonstrate the three-dimensional structure of biofilms, and revealed that the biofilms formed in the absence of $\mathrm{Co}-\mathrm{Cr}$ ions had a thickness of $42 \mu \mathrm{m}$ (S. aureus) and
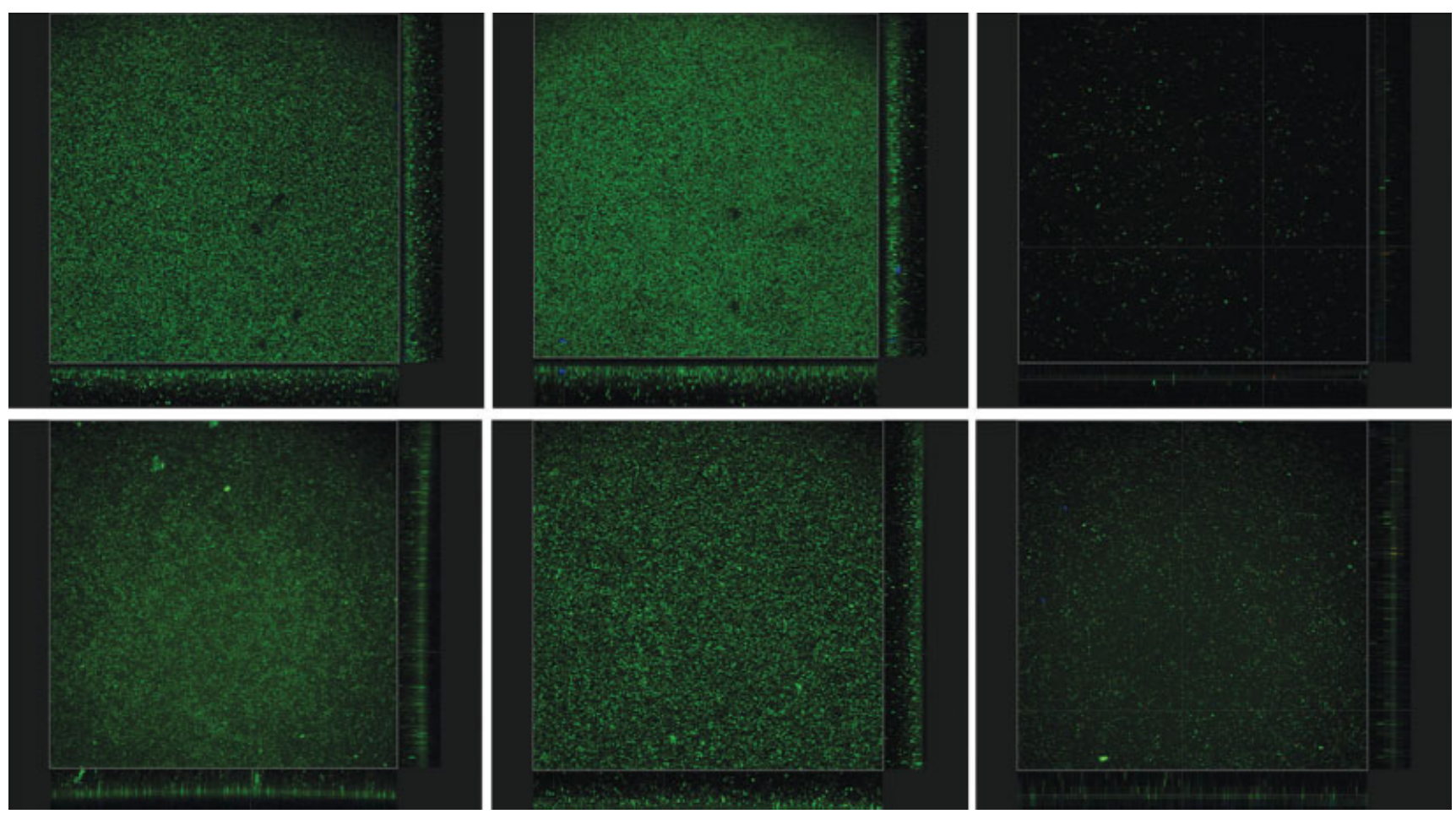

Figure 2. CLSM images $(375 \times 375 \mu \mathrm{m})$ of S. aureus 7388 (top) and CNS 5147 (bottom) biofilms, grown in the absence (left) and presence of 2/0.93 $\mu \mathrm{g} / \mathrm{L}$ (middle) and 200,000/93,000 $\mu \mathrm{g} / 1$ (right) Co-Cr ions. [Color figure can be viewed in the online issue, which is available at www.interscience.wiley.com.] 
$35 \mu \mathrm{m}$ (CNS), respectively. While in the presence of the highest concentration $\mathrm{Co}-\mathrm{Cr}$ ions $(200,000 /$ $93,000 \mu \mathrm{g} / \mathrm{L}$ ) biofilm thickness and density is remarkably reduced to $15 \mu \mathrm{m}$ and $8 \mu \mathrm{m}$, for $S$. aureus and CNS, respectively, confirming that CNS is slightly more affected. Neither dead bacteria nor slime were observed, regardless of the absence or presence of $\mathrm{Co}-$ $\mathrm{Cr}$ ions or the strain involved.

\section{DISCUSSION}

MOM-bearings for joint arthroplasty have regained popularity in the treatment of young patients because they offer wear rates low enough to prevent the bearing from wearing out in a lifetime, but little is known about the way infectious microorganisms behave toward the Co-Cr surfaces involved in MOM-bearings. Recently, Anwar et al. showed that wear debris from MOM-bearings accelerate the growth rate of planktonic bacteria. ${ }^{41}$ To our knowledge, this is the first study that focuses on the influence of cobalt and chromium ions on biofilm formation.

An intriguing novel finding from this study was that biofilm formation and planktonic growth were inhibited by a high dose of chromium and cobalt ions. The highest concentration of metal ions $(200,000 / 93,000 \mu \mathrm{g} / \mathrm{L}$ Co-Cr) used, reduced biofilm formation by $15 \%$ and $26 \%$ with respect to a control for two collections of $S$. aureus and CNS strains, respectively. The lower metal concentrations revealed no consistent influence on biofilm or on planktonic growth. CLSM images of the biofilm confirmed the results retrieved by light absorbance and showed that biofilm thickness and density were only affected by exposure to the highest concentration $\mathrm{Co}-\mathrm{Cr}$. The highest metal ion concentration caused a reduction in biofilm thickness of more than $50 \%$.

The exact role of either cobalt or chromium in staphylococcal biofilm formation is still unclear and hypothetically involves competition with $\mathrm{Fe}$ for uptake in the cell. Iron is an important nutrient element required by the bacterial metabolism, and interference with its uptake could provide an effective mechanism to contain infection. This suggestion is confirmed by a study on the effect of cobalt on Pseudomonas aeruginosa, ${ }^{42}$ demonstrating inhibition of iron-dependent metabolic activities of the bacterium leading to growth retardation and cell death.

Cobalt chromium alloys had not been available before the 1950s and it was at that moment when the first designs of MOM-bearings were described. Initially, infection rates of early MOM-bearings developed in the 1960s, such as the McKee-Farrar arthroplasty were high and ranged from $0 \%$ to $6 \%$ with antibiotic prophylaxis and from $0.5 \%$ to $11 \%$ without, but at that time in many centers no clean air enclosures were used. ${ }^{42}$ However, the durability of these designs was quite poor and at present the durability of the bearing surfaces has been improved by appropriate surface finishes and forging processes. Preliminary data over short follow-up times of these newly developed MOM-bearings show lower infection rates than of the early designs. Milosev et al. reported six revisions because of infection in a cohort of 640 total hip replacements after a 7.1-year follow up. ${ }^{43}$ In addition, Korovessis et al. reported three infections in a consecutive series of 217 total hip replacements after 6.4 years. ${ }^{8}$ However, no large, long-term outcome studies are presently available.

Although the reductions in biofilm formation observed in the present study seem to be in line with the few clinical data on infection rates of MOMbearings, it must be acknowledged that reliable information about the exact local concentrations of $\mathrm{Co}-\mathrm{Cr}$ around prostheses is not available. However, in local antibiotic treatment it is recognized that local antibiotic concentrations can become up to 5000 times higher than serum levels, ${ }^{44}$ which suggest that $\mathrm{Co}-\mathrm{Cr}$ concentrations around a MOM-bearing may be as high as $100,000 / 46,500 \mu \mathrm{g} / \mathrm{mL}$. In addition, serum levels of metal ions have demonstrated great variability from patient to patient. ${ }^{45}$ Moreover, local concentrations of $\mathrm{Co}$ and $\mathrm{Cr}$ ions in the synovial fluids will probably exceed these serum levels significantly, particularly in poorly engineered implants or in case of increased wear rate because of malpositioning of the components, impingement, or loosening.

\section{CONCLUSIONS}

In conclusion, planktonic bacterial growth, biofilm growth and thickness were significantly reduced by Co-Cr concentrations of 200,000/93,000 $\mu \mathrm{g} / \mathrm{L}$, which are higher than observed in serum, but not unlikely around a prosthesis or in synovial fluid. This suggests that MOM-bearings may be less prone to biofilm formation and subsequent infection.

\section{References}

1. Burroughs BR, Hallstrom B, Golladay GJ, Hoeffel D, Harris WH. Range of motion and stability in total hip arthroplasty with $28-, 32-, 38-$, and $44-\mathrm{mm}$ femoral head sizes. J Arthroplasty 2005;20:11-19.

2. Oparaugo PC, Clarke IC, Malchau H, Herberts P. Correlation of wear debris-induced osteolysis and revision with volumetric wear-rates of polyethylene: A survey of 8 reports in the literature. Acta Orthop Scand 2001;72:22-28.

3. Wroblewski BM. Osteolysis due to particle wear debris following total hip arthroplasty: The role of high-density polyethylene. Instr Course Lect 1994;43:289-294. 
4. Affatato S, Leardini W, Jedenmalm A, Ruggeri O, Toni A. Larger diameter bearings reduce wear in metal-on-metal hip implants. Clin Orthop Relat Res 2007;456:153-158.

5. Learmonth ID, Gheduzzi S, Vail TP. Clinical experience with metal-on-metal total joint replacements: Indications and results. Proc Inst Mech Eng [H] 2006;220:229-237.

6. Silva M, Heisel C, Schmalzried TP. Metal-on-metal total hip replacement. Clin Orthop Relat Res 2005;430:53-61.

7. Wagner $\mathrm{M}$, Wagner H. Medium-term results of a modern metal-on-metal system in total hip replacement. Clin Orthop Relat Res 2000;379:123-133.

8. Korovessis P, Petsinis G, Repanti M, Repantis T. Metallosis after contemporary metal-on-metal total hip arthroplasty. Five to nine-year follow-up. J Bone Joint Surg Am 2006;88:1183-1191.

9. Milosev I, Trebse R, Kovac S, Cor A, Pisot V. Survivorship and retrieval analysis of Sikomet metal-on-metal total hip replacements at a mean of seven years. J Bone Joint Surg Am 2006;88:1173-1182.

10. Schaffer AW, Pilger A, Engelhardt C, Zweymueller K, Ruediger HW. Increased blood cobalt and chromium after total hip replacement. J Toxicol Clin Toxicol 1999;37:839-844.

11. Back DL, Young DA, Shimmin AJ. How do serum cobalt and chromium levels change after metal-on-metal hip resurfacing? Clin Orthop Relat Res 2005;438:177-181.

12. Clarke MT, Lee PT, Arora A, Villar RN. Levels of metal ions after small- and large-diameter metal-on-metal hip arthroplasty. J Bone Joint Surg Br 2003;85:913-917.

13. Rasquinha VJ, Ranawat CS, Weiskopf J, Rodriguez JA, Skipor AK, Jacobs JJ. Serum metal levels and bearing surfaces in total hip arthroplasty. J Arthroplasty 2006;21(Suppl 2):47-52.

14. Skipor AK, Campbell PA, Patterson LM, Anstutz HC, Schmalzried TP, Jacobs JJ. Serum and urine metal levels in patients with metal-on-metal surface arthroplasty. J Mater Sci Mater Med 2002;13:1227-1234.

15. Witzleb WC, Ziegler J, Krummenauer F, Neumeister V, Guenther KP. Exposure to chromium, cobalt and molybdenum from metal-on-metal total hip replacement and hip resurfacing arthroplasty. Acta Orthop 2006;77:697-705.

16. Brodner W, Grohs JG, Bitzan P, Meisinger V, Kovarik J, Kotz R. [Serum cobalt and serum chromium level in 2 patients with chronic renal failure after total hip prosthesis implantation with metal-metal gliding contact]. Z Orthop Ihre Grenzgeb 2000;138:425-429.

17. Hallab N, Merritt K, Jacobs JJ. Metal sensitivity in patients with orthopaedic implants. J Bone Joint Surg Am 2001;83:428-436.

18. MacQuarrie RA, Fang Chen Y, Coles C, Anderson GI. Wearparticle-induced osteoclast osteolysis: The role of particulates and mechanical strain. J Biomed Mater Res B Appl Biomater 2004;69:104-112.

19. Tharani R, Dorey FJ, Schmalzried TP. The risk of cancer following total hip or knee arthroplasty. J Bone Joint Surg Am 2001;83:774-780.

20. Urban RM, Jacobs JJ, Tomlinson MJ, Gavrilovic J, Black J, Peoc'h M. Dissemination of wear particles to the liver, spleen, and abdominal lymph nodes of patients with hip or knee replacement. J Bone Joint Surg Am 2000;82:457-476.

21. Evans EJ, Benjamin M. The effect of grinding conditions on the toxicity of cobalt-chrome-molybdenum particles in vitro. Biomaterials 1987;8:377-384.

22. Ladon D, Doherty A, Newson R, Turner J, Bhamra M, Case $\mathrm{CP}$. Changes in metal levels and chromosome aberrations in the peripheral blood of patients after metal-on-metal hip arthroplasty. J Arthroplasty 2004;19(Suppl 3):78-83.

23. Willert HG, Semlitsch M. Tissue reactions to plastic and metallic wear products of joint endoprostheses. Clin Orthop Relat Res 1996;333:4-14.

24. Visuri T, Pukkala E, Paavolainen P, Pulkkinen P, Riska EB. Cancer risk after metal on metal and polyethylene on metal total hip arthroplasty. Clin Orthop Relat Res 1996;(329 Suppl):S280-S289.

25. Rae T. The toxicity of metals used in orthopaedic prostheses. An experimental study using cultured human synovial fibroblasts. J Bone Joint Surg Br 1981;63:435-440.

26. Amstutz HC, Le Duff MJ, Beaule PE. Prevention and treatment of dislocation after total hip replacement using large diameter balls. Clin Orthop Relat Res 2004;429:108-116.

27. Blom AW, Taylor AH, Pattison G, Whitehouse S, Bannister GC. Infection after total hip arthroplasty. The Avon experience. J Bone Joint Surg Br 2003;85:956-959.

28. Costerton JW, Stewart PS, Greenberg EP. Bacterial biofilms: A common cause of persistent infections. Science 1999;284:1318-1322.

29. Costerton JW, Lewandowski Z, Caldwell DE, Korber DR, Lappin-Scott HM. Microbial biofilms. Annu Rev Microbiol 1995;49:711-745.

30. Nickel JC, Ruseska I, Wright JB, Costerton JW. Tobramycin resistance of Pseudomonas aeruginosa cells growing as a biofilm on urinary catheter material. Antimicrob Agents Chemother 1985;27:619-624.

31. Vincent KR, Vincent HK, Lee LW, Weng J, Alfano AP. Outcomes after inpatient rehabilitation of primary and revision total hip arthroplasty. Arch Phys Med Rehabil 2006;87:1026-1032.

32. Bozic KJ, Ries MD. The impact of infection after total hip arthroplasty on hospital and surgeon resource utilization. J Bone Joint Surg Am 2005;87:1746-1751.

33. Best JT. Revision total hip and total knee arthroplasty. Orthop Nurs 2005;24:174-179.

34. Harrison JJ, Turner RJ, Ceri H. Persister cells, the biofilm matrix and tolerance to metal cations in biofilm and planktonic Pseudomonas aeruginosa. Environ Microbiol 2005;7:981-994.

35. Cobb AG, Schmalzreid TP. The clinical significance of metal ion release from cobalt-chromium metal-on-metal hip joint arthroplasty. Proc Inst Mech Eng [H] 2006;220:385-398.

36. Shetty VD, Villar RN. Development and problems of metalon-metal hip arthroplasty. Proc Inst Mech Eng [H] 2006;220: 371-377.

37. Scholes SC, Unsworth A. The tribology of metal-on-metal total hip replacements. Proc Inst Mech Eng [H] 2006;220:183-194.

38. Rafiq I, Gambhir AK, Wroblewski BM, Kay PR. The microbiology of infected hip arthroplasty. Int Orthop 2006;30:532-535.

39. Neut D, van Horn JR, van Kooten TG, van der Mei HC, Busscher HJ. Detection of biomaterial-associated infections in orthopaedic joint implants. Clin Orthop Relat Res 2003;413: 261-268.

40. Anissian L, Stark A, Dahistrand H, Granberg B, Good V, Bucht E. Cobalt ions influence proliferation and function of human osteoblast-like cells. Acta Orthop Scand 2002;73:369-374.

41. Anwar HA, Hart AJ, Visuvanathan S, Aldam CH.The effects of heavy metals from total hip replacement wear debris on bacterial growth? Abstract book, $26^{\text {th }}$ Annual Meeting of the European Bone \& Joint Infection Society with participation of Musculoskeletal Infection Society of North America, 20-22 September 2007, Corfu, Greece.

42. Amstutz HC, Grigoris P. Metal on metal bearings in hip arthroplasty. Clin Orthop Relat Res 1996;329:S11-S34.

43. Milosev I, Trebse R, Kovac S, Cor A, Pisot V. Survivorship and retrieval analysis of Sikomet metal-on-metal total hip replacements at a mean of seven years. J Bone Joint Surg Am 2006;88:1173-1182.

44. Wahlig H, Dingeldein E, Bergmann R, Reuss K. The release of gentamicin from polymethylmethacrylate beads. An experimental and pharmacokinetic study. J Bone Joint Surg $\mathrm{Br}$ 1978;60:270-275.

45. Heisel C, Silva M, Skipor AK, Jacobs JJ, Schmalzried TP. The relationship between activity and ions in patients with metalon-metal bearing hip prostheses. J Bone Joint Surg Am 2005;87:781-787. 